\title{
REGRESSION ANALYSIS BETWEEN SEDIMENT TRANSPORT RATES AND STREAM DISCHARGE FOR THE NESTOS RIVER, GREECE
}

\section{ANGELIS \\ A. METALLINOS \\ V. HRISSANTHOU*}

Received: $20 / 3 / 12$

Accepted: $27 / 7 / 12$
Department of Civil Engineering

Democritus University of Thrace

67100 Xanthi, Greece

\section{ABSTRACT}

Systematic measurements of sediment transport rates and water discharge were conducted in the Nestos River (Greece), at a place located between the outlet of Nestos River basin and the river delta. This basin area is about $838 \mathrm{~km}^{2}$ and lies downstream of the Platanovrysi Dam. Separate measurements of bed load transport and suspended load transport were performed at certain cross sections of the Nestos River.

In this study, relationships between sediment transport rates and stream discharge for the Nestos River are presented. A nonlinear regression curve $\left(4^{\text {th }}\right.$ degree polynomial curve; $r^{2}$ equals 0.62$)$ between bed load transport rates and stream discharge, on the basis of 63 measurements, was developed. In addition, a nonlinear regression curve $\left(5^{\text {th }}\right.$ degree polynomial curve; $r^{2}$ equals 0.95$)$ between suspended load transport rates and stream discharge, on the basis of 65 measurements, was developed.

The relatively high $r^{2}$ values indicate that both bed load transport rates and, especially, suspended load transport rates can be predicted as a function of the stream discharge in the Nestos River. However, the reliability of the regression equations would have been higher if more measured data were available.

KEYWORDS: Sediment transport, Bed load, Suspended load, Stream discharge, Measurements, Regression analysis, Nestos River.

\section{INTRODUCTION}

Stream sediment transport is classified into bed load transport and suspended load transport on the basis of the two different motion patterns. Bed load transport depends mainly on the hydraulic characteristics of the streams (e.g. discharge; Maniak, 1988), consists mainly of coarse material, and originates from stream bed erosion. Suspended load originates from soil erosion products inflowing into the streams from the surrounding basins and stream bed erosion, and depends on both hydraulic and rainfall characteristics (e.g. rainfall depth, intensity). This can be explained as follows: rainfall and runoff cause soil detachment and hence erosion products can reach the streams and are then transported in the streams as suspended materials. However, the measurements of suspended load transport are not usually conducted promptly after rainfall events, and hence suspended load transport mainly originates from river bed erosion. On this basis, both bed load transport and suspended load transport are correlated with stream discharge.

A common method to represent the dependence (linear or nonlinear) between two measured variables (in this case between bed / suspended load transport and stream discharge) lies on the regression analysis. The dependence between two variables could be depicted graphically using a curve, whereas the degree of the linear dependence is usually expressed by the correlation coefficient (Pearson product-moment correlation coefficient). Numerous regression relationships 
between suspended load concentration or suspended load transport rates and stream discharge, for different regions in the world, can be found in the literature (see among others, Walling, 1977; Griffiths, 1982; Córdova and González, 1997; Asselman, 2000; Achite and Ouillon, 2007; Sadeghi et al., 2008). Estimates of suspended load transport rates in the Nestos River can be found in Poulos and Alexandrakis (2005).

Bed load is usually estimated as the percentage of suspended load at the outlet of a basin. Bed load transport rates can be computed at a river cross section by semi-empirical bed load formulas (e.g. Meyer-Peter and Müller, 1949; Einstein, 1950). Measurements of bed load transport rates in natural streams is more difficult to be acquired compared to suspended load transport rates, mainly because of the bed unevenness or bed forms; hence the lack of observed data.

While regression analysis is a very useful tool to predict sediment transport rates at a river cross section as a function of stream discharge, the interaction between stream water and river bed, e.g. river bed erosion and deposition, is not considered in detail. This study aims to identify the relationship between sediment transport rates (bed load transport, suspended load transport) and stream discharge using measured data from the Nestos River, Greece. The paper is organised as follows. In Section 2, the study area and data are introduced. Section 3 presents the regression relationships and their statistical significance. Finally, Section 4 states the discussion and the conclusion.

\section{STUDY AREA AND MEASURED DATA}

The Nestos River basin, considered in this study, drains an area of $838 \mathrm{~km}^{2}$, and lies downstream of the Platanovrysi Dam. The basin outlet is located at Toxotes. The basin is covered by forest (48\%), bush $(20 \%)$, cultivated land $(24 \%)$, urban areas $(2 \%)$ and no significant vegetation $(6 \%)$. The altitude ranges between 80 and $1600 \mathrm{~m}$, whereas the length of the Nestos River is $55 \mathrm{~km}$. The basin is divided into 20 sub-basins with areas between 13 and $80 \mathrm{~km}^{2}$. The mean slope of the sub-basins ranges between 23 and $58 \%$, the mean slope of the main stream of the sub-basins ranges between 2.5 and $20 \%$, whereas the mean slope of the Nestos River in the basin is $0.35 \%$.

Systematic measurements of water discharge, suspended load transport and bed load transport were conducted in the Nestos River (Greece) over the 2005-2009 period, at a site located between the basin outlet (Toxotes) and the river delta (see among others, Evrenoglou et al., 2010; Kladogenis and Haliloglou, 2007; Livaditis and Kapoglis, 2006). The width of the cross sections, where the measurements were performed, varies between 7 and $152 \mathrm{~m}$. The cross section was divided into subsections, and the mean velocity was measured separately in each subsection using an impeller flow meter.

Measurements of suspended load transport and bed load transport were carried out at the same time as the discharge measurements. Water samples should be taken from each subsection, and the concentration of suspended load for each subsection should be determined in a chemical laboratory. The concentration of suspended load for the whole cross section is determined from Equation (1). However, water samples were taken only from the middle of the cross sections, and the concentration of suspended load was determined only for the middle of a cross section, in the Laboratory of Ecological Engineering and Technology, Department of Environmental Engineering, Democritus University of Thrace, Greece. This value is representative for the whole cross section.

$C_{s}=\sum_{i=1}^{m} C_{s i} Q_{i} / \sum_{i=1}^{m} Q_{i}$

where

$C_{S}$ : concentration of suspended load for the whole cross section $\left(\mathrm{kg} \mathrm{m}^{-3}\right)$

$C_{S i}$ : concentration of suspended load for the subsection $i\left(\mathrm{~kg} \mathrm{~m}^{-3}\right)$

$Q_{i}$ : water discharge for the subsection $i\left(\mathrm{~m}^{3} \mathrm{~s}^{-1}\right)$

$m$ : number of the subsections

The transport rate of suspended load for the whole cross section, $m_{s}\left(\mathrm{~kg} \mathrm{~s}^{-1}\right)$, was determined from the following relationship: 
$m_{\mathrm{s}}=C_{s} \sum_{i=1}^{m} Q_{i}$

For the measurement of bed load transport, a sediment trap was put on the bed, in the middle of the whole cross section. In order to determine the bed load transport rate, the dry mass of the trapped sediment is divided by the measurement duration and the width of the sediment trap.

Table 1 presents the date of the measurements, the stream discharge, the suspended load transport rates and the bed load transport rates. 63 measurements of bed load transport rates and 65 measurements of suspended load transport rates are contained in Table 1. The stream discharge varies between 0.39 and $87 \mathrm{~m}^{3} \mathrm{~s}^{-1}$, the suspended load transport rates vary between 0.47 and $1165 \mathrm{~g} \mathrm{~s}^{-1}$, while the bed load transport rates between 0.0004 and $0.059 \mathrm{~kg} \mathrm{~m}^{-1} \mathrm{~s}^{-1}$.

Table 1. Measured values of stream discharge, suspended load transport rates and bed load transport rates

\begin{tabular}{|c|c|c|c|}
\hline Date & $\begin{array}{c}\text { Stream discharge } \\
\left(\mathrm{m}^{3} \mathrm{~s}^{-1}\right)\end{array}$ & $\begin{array}{c}\text { Suspended load } \\
\text { transport rate } \\
\left(\mathrm{g} \mathrm{s}^{-1}\right)\end{array}$ & $\begin{array}{c}\text { Bed load } \\
\text { transport rate } \\
\left(\mathrm{kg} \mathrm{m}^{-1} \mathrm{~s}^{-1}\right)\end{array}$ \\
\hline $16-9-2005$ & 16.96 & 34.0 & 0.012 \\
\hline $19-9-2005$ & 13.17 & 40.0 & 0.014 \\
\hline $23-9-2005$ & 25.48 & 255.0 & 0.054 \\
\hline 24-9-2005 & 21.25 & 47.0 & 0.039 \\
\hline $25-9-2005$ & 16.67 & 67.0 & 0.051 \\
\hline $26-9-2005$ & 14.17 & 42.51 & 0.024 \\
\hline $27-9-2005$ & 17.77 & 88.85 & 0.030 \\
\hline $28-9-2005$ & 19.50 & 156.0 & 0.018 \\
\hline $29-9-2005$ & 16.65 & 116.55 & 0.044 \\
\hline $30-9-2005$ & 18.49 & 73.96 & 0.027 \\
\hline $11-7-2008$ & 6.98 & 20.94 & 0.002 \\
\hline $13-7-2008$ & 6.37 & 31.9 & 0.001 \\
\hline $15-7-2008$ & 5.79 & 46.35 & 0.002 \\
\hline $29-10-2008$ & 2.44 & 5.37 & 0.003 \\
\hline $30-10-2008$ & 2.73 & 6.80 & 0.003 \\
\hline $1-11-2008$ & 2.69 & 6.50 & 0.0025 \\
\hline $2-11-2008$ & 2.84 & 5.90 & 0.003 \\
\hline $3-11-2008$ & 3.09 & 8.30 & 0.003 \\
\hline $13-7-2009$ & 49.24 & 82.47 & - \\
\hline $14-7-2009$ & 45.71 & 141.14 & 0.004 \\
\hline $15-7-2009$ & 33.38 & 44.66 & 0.0005 \\
\hline $16-7-2009$ & 86.06 & 1165.05 & 0.077 \\
\hline $16-7-2009$ & 28.74 & 24.43 & 0.003 \\
\hline $17-7-2009$ & 86.58 & 543.30 & 0.096 \\
\hline $17-7-2009$ & 21.62 & 17.30 & 0.001 \\
\hline $18-7-2009$ & 74.84 & 203.95 & 0.046 \\
\hline 28-9-2009 & 17.89 & - & 0.003 \\
\hline $28-9-2009$ & 15.45 & - & 0.013 \\
\hline $29-9-2009$ & 20.62 & - & 0.014 \\
\hline 29-9-2009 & 16.15 & - & 0.008 \\
\hline $30-9-2009$ & 14.14 & - & 0.002 \\
\hline $29-12-2009$ & 58.98 & 0.86 & 0.0004 \\
\hline 29-12-2009 & 52.94 & 1.41 & 0.002 \\
\hline $3-1-2010$ & 50.14 & 0.74 & 0.007 \\
\hline $3-1-2010$ & 48.27 & 0.52 & 0.004 \\
\hline $11-1-2010$ & 45.72 & 0.48 & 0.009 \\
\hline $11-1-2010$ & 44.45 & 0.47 & 0.007 \\
\hline $18-1-2010$ & 62.41 & 0.68 & 0.012 \\
\hline $18-1-2010$ & 55.30 & 0.62 & 0.016 \\
\hline
\end{tabular}


Table 1 (continued). Measured values of stream discharge, suspended load transport rates and bed load transport rates

\begin{tabular}{|c|c|c|c|}
\hline Date & $\begin{array}{c}\text { Stream discharge } \\
\left(\mathrm{m}^{3} \mathrm{~s}^{-1}\right)\end{array}$ & $\begin{array}{c}\text { Suspended load } \\
\text { transport rate } \\
\left(\mathrm{g} \mathrm{s}^{-1}\right)\end{array}$ & $\begin{array}{c}\text { Bed load } \\
\text { transport rate } \\
\left(\mathrm{kg} \mathrm{m}^{-1} \mathrm{~s}^{-1}\right)\end{array}$ \\
\hline $20-7-2010$ & 2.62 & 5.77 & 0.015 \\
\hline $21-7-2010$ & 3.95 & 9.90 & 0.043 \\
\hline $22-7-2010$ & 4.22 & 10.14 & 0.050 \\
\hline $22-7-2010$ & 4.13 & 8.70 & 0.059 \\
\hline $26-7-2010$ & 6.20 & 16.70 & 0.0425 \\
\hline $27-7-2010$ & 4.80 & 11.0 & 0.060 \\
\hline $29-7-2010$ & 3.76 & 9.0 & 0.064 \\
\hline $3-8-2010$ & 3.16 & 8.20 & 0.035 \\
\hline $2-11-2010$ & 2.06 & 6.78 & 0.0485 \\
\hline $2-11-2010$ & 1.46 & 3.64 & 0.019 \\
\hline $3-11-2010$ & 1.88 & 4.52 & 0.021 \\
\hline $5-11-2010$ & 1.49 & 3.57 & 0.015 \\
\hline $5-11-2010$ & 1.75 & 4.72 & 0.042 \\
\hline $18-11-2010$ & 1.66 & 21.09 & 0.007 \\
\hline $24-11-2010$ & 2.28 & 61.70 & 0.007 \\
\hline $25-11-2010$ & 1.55 & 47.93 & 0.017 \\
\hline $25-11-2010$ & 1.24 & 13.39 & 0.021 \\
\hline $26-11-2010$ & 1.65 & 54.47 & 0.016 \\
\hline $3-12-2010$ & 1.55 & 1.87 & 0.0085 \\
\hline $3-12-2010$ & 2.03 & 1.80 & 0.004 \\
\hline $3-12-2010$ & 0.80 & 0.88 & 0.005 \\
\hline $4-12-2010$ & 0.69 & 0.68 & 0.002 \\
\hline $4-12-2010$ & 0.69 & 0.55 & 0.002 \\
\hline $5-12-2010$ & 0.89 & 1.07 & 0.007 \\
\hline $24-3-2011$ & 3.27 & 99.06 & 0.019 \\
\hline $24-3-2011$ & 3.70 & 101.50 & 0.049 \\
\hline 29-3-2011 & 2.83 & 79.27 & 0.015 \\
\hline $2-4-2011$ & 3.40 & 36.03 & 0.030 \\
\hline 2-4-2011 & 3.28 & 39.52 & 0.018 \\
\hline $7-4-2011$ & 1.77 & 75.68 & 0.020 \\
\hline $9-4-2011$ & 1.05 & 33.23 & 0.010 \\
\hline $9-4-2011$ & 0.60 & 20.09 & 0.009 \\
\hline $10-4-2011$ & 0.39 & 12.59 & 0.008 \\
\hline $10-4-2011$ & 0.64 & 20.93 & 0.008 \\
\hline
\end{tabular}

\section{REGRESSION RELATIONSHIPS}

Simple nonlinear regression relationships are developed for the Nestos River basin. The regression analysis relates the following variables:

- Suspended load transport rates versus stream discharge

- Bed load transport rates versus stream discharge

The coefficient of determination $\left(r^{2}\right.$ : square of the Pearson product-moment correlation coefficient in the case of a linear regression) was used to indicate how well the regression line approximates the measured data points. The variables of the regression analysis, the types of the regression curves, the values of the coefficients of determination and the number of sets of measured data for suspended load transport rates and stream discharge, as well as for bed load transport rates and stream discharge are presented in Table 2.

Figure 1 illustrates the relationship between suspended load transport rates and stream discharge using polynomial distribution of $5^{\text {th }}$ degree to fit the 65 sets of measured data. The coefficient of determination obtains the value 0.95 . Additionally, Figure 1 shows a relatively higher scattering during the high streamflows, which implies a relatively higher uncertainty in the prediction of the 
suspended load transport rates for the high streamflows. The above result could be explained by the fact that the water samples are not very representative during the high streamflows, regarding suspended load concentration.

Figure 2 illustrates the relationship between bed load transport rates and stream discharge using polynomial distribution of $4^{\text {th }}$ degree to fit the 63 sets of measured data. The coefficient of determination obtains the value 0.62. Additionally, Figure 2 shows a higher scattering during the low streamflows, which implies a higher uncertainty in the prediction of the bed load transport rates for the low streamflows. The above result could be explained by the fact that the sediment quantity captured in the sediment trap during the low streamflows is not very representative due to the bed unevenness.

In the computational process of the regression analysis, the F-test was also used to control the adaptability of the regression model to the measured data (suspended load transport rate or bed load transport rate). Moreover, the lower and upper bounds of the coefficients of the polynomials at a confidence interval of $95 \%$ were determined (Table 3 ).

For comparison reasons, a linear regression analysis was applied to 62 sets of measured data for suspended load transport rates and stream discharge. Figure 3 illustrates the linear relationship between suspended load transport rates and stream discharge $\left(r^{2}\right.$ equals 0.51$)$. A similar linear regression analysis was repeated to the sets of measured data for bed load transport rates and stream discharge. However, in this case, the $r^{2}$ obtains very low values (about 0.04 ), not depending on the number of the sets of measured data.

Apart from the $5^{\text {th }}$ degree polynomial curve between suspended load transport rate and stream discharge, the following nonlinear regression curves were fitted to the measured data: polynomial of $2^{\text {nd }}, 3^{\text {rd }}$ and $4^{\text {th }}$ degree (see Table 4), logarithmic, exponential and hyperbolic; however, acceptable $r^{2}$ values have only been achieved for the polynomial curves.

Apart from the $4^{\text {th }}$ degree polynomial curve between bed load transport rate and stream discharge, the following nonlinear regression curves were fitted to the measured data: polynomial of $2^{\text {nd }}$ and $3^{\text {rd }}$ degree (see Table 5), logarithmic, exponential and hyperbolic; however, acceptable $r^{2}$ values have only been achieved for the polynomial curves.

Table 2. Nonlinear regression relationships for suspended load transport rates and bed load transport rates

\begin{tabular}{ccc}
\hline & $\begin{array}{c}\text { Suspended load transport } \\
\text { rate }\left(\mathrm{g} \mathrm{s}^{-1}\right) \text { versus stream } \\
\text { discharge }\left(\mathrm{m}^{3} \mathrm{~s}^{-1}\right)\end{array}$ & $\begin{array}{c}\text { Bed load transport rate } \\
\left(\mathrm{kg} \mathrm{m}^{-1} \mathrm{~s}^{-1}\right) \text { versus stream } \\
\text { discharge }\left(\mathrm{m}^{3} \mathrm{~s}^{-1}\right)\end{array}$ \\
\hline $\begin{array}{c}\text { polynomial } \\
\text { Type of regression curve }\end{array}$ & $\begin{array}{c}\text { polynomial } \\
\mathrm{y}=\left(3.05 \cdot 10^{-6}\right) \mathrm{x}^{5}-\left(4.44 \cdot 10^{-4}\right) \mathrm{x}^{4} \\
+\left(2.32 \cdot 10^{-2}\right) \mathrm{x}^{3}-\left(5.96 \cdot 10^{-1}\right) \mathrm{x}^{2} \\
+8.58 \mathrm{x}+5.89\end{array}$ & $\begin{array}{c}\mathrm{y}=-\left(7.05 \cdot 10^{-9}\right) \mathrm{x}^{4} \\
+\left(1.85 \cdot 10^{-6}\right) \mathrm{x}^{3}-\left(1.24 \cdot 10^{-4}\right) \mathrm{x}^{2} \\
+\left(2.36 \cdot 10^{-3}\right) \mathrm{x}+7.99 \cdot 10^{-3}\end{array}$ \\
$\begin{array}{c}\text { Coefficient of determination } \\
\left(r^{2}\right)\end{array}$ & 0.95 & 0.62 \\
\hline $\begin{array}{c}\text { Number of sets } \\
\text { of measured data }\end{array}$ & & \\
\hline
\end{tabular}




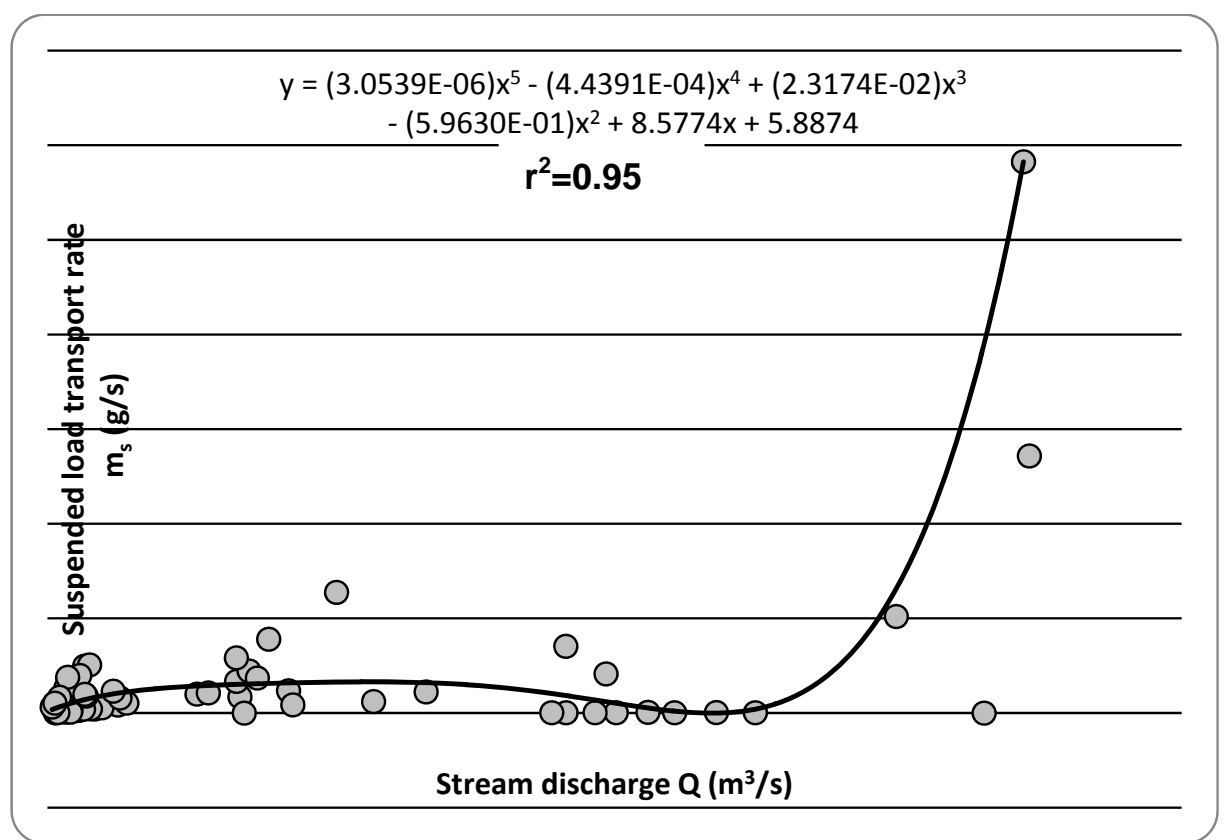

Figure 1. Relationship between suspended load transport rate and stream discharge using a $5^{\text {th }}$ degree polynomial distribution

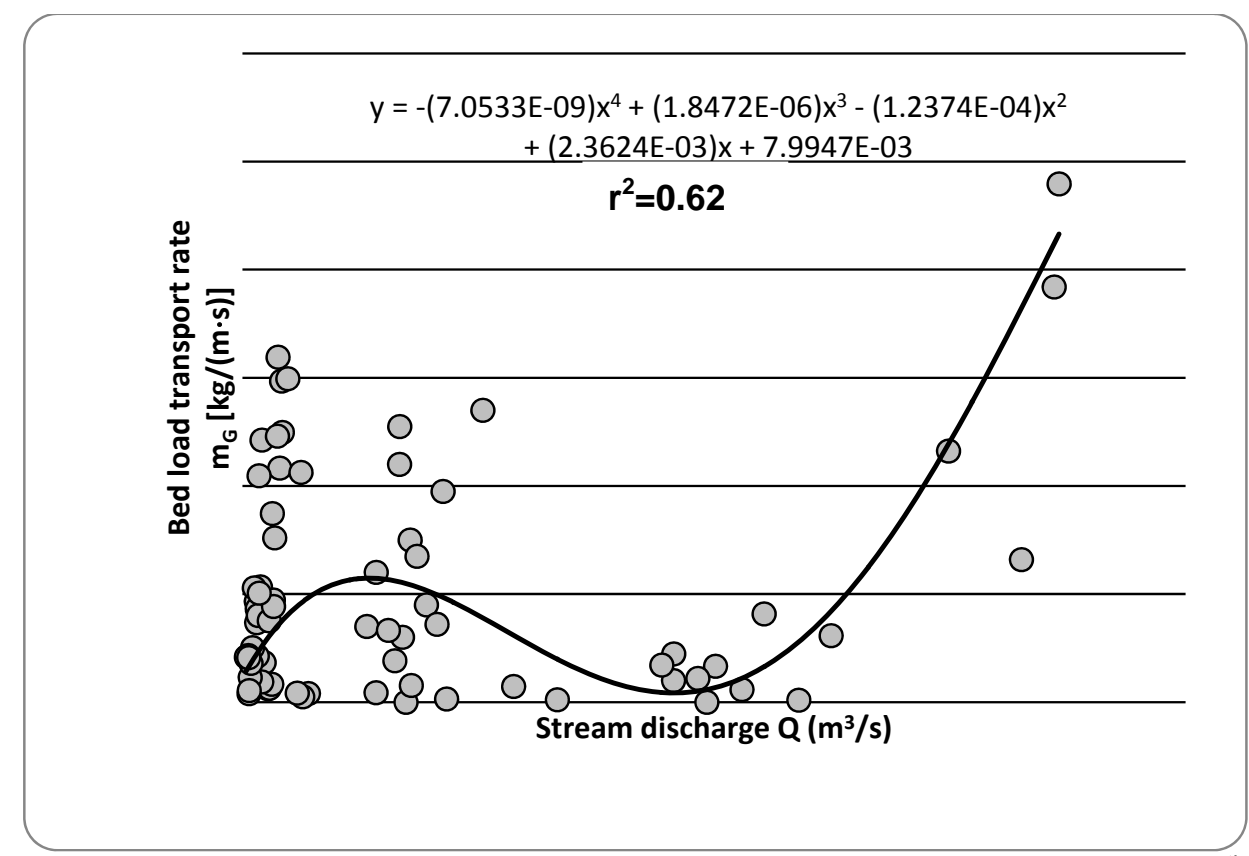

Figure 2. Relationship between bed load transport rate and stream discharge using a $4^{\text {th }}$ degree polynomial distribution

Table 3. Lower and upper bounds of the coefficients of the polynomials

\begin{tabular}{llllll}
\hline Coefficients & Lower bound & Upper bound & Coefficients & Lower bound & Upper bound \\
\hline 5.89 & -17.08 & 28.85 & $7.99 \cdot 10^{-3}$ & 0.002 & 0.014 \\
8.58 & -2.24 & 19.40 & $2.36 \cdot 10^{-3}$ & 0.001 & 0.004 \\
$-5.96 \cdot 10^{-1}$ & -1.63 & 0.43 & $-1.24 \cdot 10^{-4}$ & -0.001 & $-9.09 \cdot 10^{-6}$ \\
$2.32 \cdot 10^{-2}$ & -0.013 & 0.059 & $1.85 \cdot 10^{-6}$ & $-4.89 \cdot 10^{-7}$ & $4.18 \cdot 10^{-6}$ \\
$-4.44 \cdot 10^{-4}$ & -0.001 & $7.76 \cdot 10^{-5}$ & $-7.05 \cdot 10^{-9}$ & $-2.15 \cdot 10^{-8}$ & $7.43 \cdot 10^{-9}$ \\
$3.05 \cdot 10^{-6}$ & $4.15 \cdot 10^{-7}$ & $5.69 \cdot 10^{-6}$ & & & \\
\hline
\end{tabular}




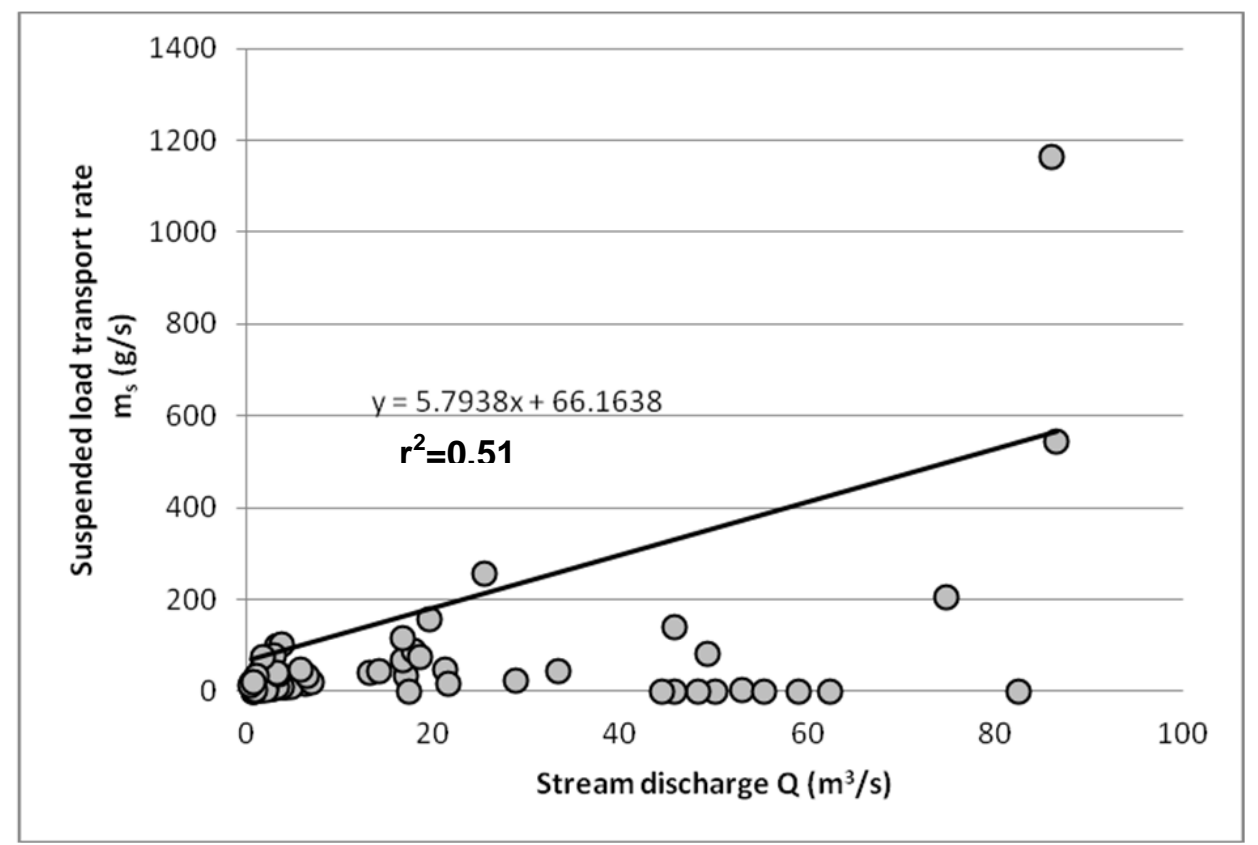

Figure 3. Linear relationship between suspended load transport rate and stream discharge

Table 4. Nonlinear regression relationships for suspended load transport rates

\begin{tabular}{lccc}
\hline $\begin{array}{l}\text { Regression } \\
\text { curve }\end{array}$ & $\begin{array}{l}\text { Number of } \\
\text { sets of } \\
\text { measured data }\end{array}$ & Regression equation & $r^{2}$ \\
\hline $\begin{array}{l}\text { Polynomial } \\
\text { of second } \\
\text { degree }\end{array}$ & 65 & $y=0.22 x^{2}-10.29 x+64.03$ & 0.60 \\
$\begin{array}{l}\text { Polynomial } \\
\text { of third } \\
\text { degree }\end{array}$ & 65 & $y=\left(7.53 \cdot 10^{-3}\right) x^{3}-\left(6.62 \cdot 10^{-1}\right) x^{2}+14.37 x+47.77$ & 0.92 \\
$\begin{array}{l}\text { Polynomial } \\
\text { of fourth } \\
\text { degree }\end{array}$ & 65 & $y=\left(1.57 \cdot 10^{-4}\right) x^{4}-\left(1.73 \cdot 10^{-2}\right) x^{3}+\left(5.05 \cdot 10^{-1}\right) x^{2}$ & 0.95 \\
\hline
\end{tabular}

Table 5. Nonlinear regression relationships for bed load transport rates

\begin{tabular}{lccc}
\hline $\begin{array}{l}\text { Regression } \\
\text { curve }\end{array}$ & $\begin{array}{l}\text { Number of } \\
\text { sets of } \\
\text { measured data }\end{array}$ & Regression equation & $r^{2}$ \\
\hline $\begin{array}{l}\text { Polynomial } \\
\text { of second } \\
\text { degree }\end{array}$ & 63 & $\mathrm{y}=\left(1.58 \cdot 10^{-5}\right) \mathrm{x}^{2}-\left(7.86 \cdot 10^{-4}\right) \mathrm{x}+1.72 \cdot 10^{-2}$ & 0.37 \\
$\begin{array}{l}\text { Polynomial } \\
\text { of third } \\
\text { degree }\end{array}$ & 63 & $\left.\mathrm{y}=\left(7.15 \cdot 10^{-7}\right) \mathrm{x}^{3}-\left(6.96 \cdot 10^{-5}\right) \mathrm{x}^{2}+1.60 \cdot 10^{-2}\right) \mathrm{x}$ & 0.62 \\
\hline
\end{tabular}




\section{DISCUSSION AND CONCLUSION}

As expected, the analysis showed that there is a positive relationship between suspended load and bed load transport rates and streamflow. High $r^{2}$ values in the suspended load transport rates stream discharge relationship are observed; however, significantly smaller $r^{2}$ values are observed in the bed load transport rates - stream discharge relationship. This difference could be due to higher errors in the bed load data; the suspended load measurements are based on water sample collection, whereas the bed load measurements are based on means of the sediment trap, which are not very representative because of the bed unevenness. For example, in some cases, equal values of bed load transport rate for different values of stream discharge were measured (see Table 1).

In a previous study (Metallinos and Hrissanthou, 2011), a hyperbolic regression curve was fitted to the measured data of suspended load transport rates and stream discharge in the Nestos River. A high $r^{2}$ value (0.85) was achieved using 18 data sets. In addition, an exponential regression curve was fitted to the measured data of bed load transport rates and stream discharge in the same river, which resulted to a $0.61 r^{2}$ value using 23 data sets. Consequently and as it would be expected, the number of data sets seems to influence the type and fitting of the regression curve.

The linear regression analysis resulted to an acceptable $r^{2}$ value $(0.51)$ in the suspended load transport rates - stream discharge relationship, and to an unacceptable $r^{2}$ value $(0.04)$ in the bed load transport rates - stream discharge relationship.

The suspended sediment measurements are not very precise because the concentration of the suspended sediment, in contrast to the stream discharge, was not determined separately for each subsection of the cross section considered. The above concentration was determined only in the middle of the cross section considered.

A direct comparison of the stream discharge and suspended load transport rate measurements reported in the present study, and those presented in Poulos and Alexandrakis (2005) for the Nestos River, is not reasonable because the latter measurements are given on a monthly time basis, originate from a long time period $(1965-1982)$ and refer to a basin area of $4393 \mathrm{~km}^{2}$. At this point, it must be mentioned that the measurements reported in Poulos and Alexandrakis (2005) were performed at Temenos, before the construction of the Thisavros and the Platanovrysi Dams. In contrast, the measurements given in this study are instantaneous and refer to a basin area of 838 $\mathrm{km}^{2}$, that is located between the Platanovrysi Dam and the Nestos River delta.

Overall, the relatively high coefficients of determination indicate that both suspended load transport rates and bed load transport rates can be predicted as a function of the stream discharge in the Nestos River. It is believed that the reliability of the nonlinear regression equations would have been higher if more measured data were available: 65 sets were available for the suspended load transport rates and 63 sets for the bed load transport rates.

\section{REFERENCES}

1. 1. Achite M. and Ouillon S., (2007). Suspended sediment transport in a semiarid watershed, Wadi Abd, Algeria (1973-1995), Journal of Hydrology, 343(3-4), 187-202.

2. Asselman N.E.M., (2000). Fitting and interpretation of sediment rating curves, Journal of Hydrology, 234(3-4), 228-248.

3. Córdova J.R. and González M., (1997). Sediment yield estimation in small watersheds based on streamflow and suspended sediment discharge measurements, Soil Technology, 11(1), 57-65.

4. Einstein H.A., (1950). The bed-load function for sediment transportation in open channel flows, U.S. Department of Agriculture, Soil Conservation Service, Technical Bulletin no. 1026.

5. Evrenoglou Th., Markidis Ch. and Spanos D., (2010). Measurements of bed load transport and suspended load transport in Nestos River - Computation of bed load transport according to MeyerPeter and Müller, Diploma Thesis, Department of Civil Engineering, Democritus University of Thrace, Xanthi, Greece (in Greek). 
6. Griffiths G.A., (1982). Spatial and temporal variability in suspended sediment yields of North Island basins, New Zealand, Water Resources Bulletin, 18(4), 575-584.

7. Kladogenis P. and Haliloglou M., (2007). Measurements of water discharge and sediment transport in Nestos River, Diploma Thesis, Department of Civil Engineering, Democritus University of Thrace, Xanthi, Greece (in Greek).

8. Livaditis A. and Kapoglis E., (2006). Computations and measurements of sediment transport in Nestos River, Diploma Thesis, Department of Civil Engineering, Democritus University of Thrace, Xanthi, Greece (in Greek).

9. Maniak U., (1988). Hydrologie und Wasserwirtschaft - Eine Einführung für Ingenieure, SpringerVerlag, Berlin, Heidelberg, New York.

10. Metallinos A. and Hrissanthou V., (2011). Regression relationships between sediment transport rates and stream discharge for the Nestos River, Greece, $12^{\text {th }}$ International Conference on Environmental Science and Technology (CEST2011), Rhodes, Greece, Vol. A, pp. A-1235 - A1242 (CD-ROM).

11. Meyer-Peter E. and Müller R., (1949). Eine Formel zur Berechnung des Geschiebetriebs, Schweizer Bauzeitung, 67. Jahrgang, 3, 29-32.

12. Poulos S. and Alexandrakis G., (2005). Seasonal fluctuation of the sediments (in suspension) yield of parts of Greek river catchments and its relation to the corresponding values of water yield, Seventh Panhellenic Hydrogeology Conference, Greek Hydrogeological Society, Athens, Greece, 437-444 (in Greek with abstract in English).

13. Sadeghi S.H.R., Mizuyama T., Miyata S., Gomi T., Kosugi T., Fukushima T., Mizugaki S. and Onda Y., (2008). Development, evaluation and interpretation of sediment rating curves for a Japanese small mountainous reforested watershed, Geodema, 144(1-2), 198-211.

14. Walling D.E., (1977). Assessing the accuracy of suspended sediment rating curves for a small basin, Water Resources Research, 13(3), 531-538. 